\title{
Reciprocal human-natural system feedback loops within the invasion process
}

\author{
James S. Sinclair', Jeffrey A. Brown², Julie L. Lockwood ${ }^{3}$ \\ I Aquatic Ecology Laboratory, Ohio State University, Ohio, USA 2 Julie Ann Wrigley Global Institute of \\ Sustainability, Arizona State University, Arizona, USA 3 Ecology, Evolution and Natural Resources, Rutgers \\ University, New Jersey, USA
}

Corresponding author: James S. Sinclair (sinclair.130@osu.edu)

Academic editor: T. A. Zengeya | Received 29 March 2020 | Accepted 17 August 2020 | Published 15 October 2020

Citation: Sinclair JS, Brown JA, Lockwood JL (2020) Reciprocal human-natural system feedback loops within the invasion process. In: Wilson JR, Bacher S, Daehler CC, Groom QJ, Kumschick S, Lockwood JL, Robinson TB, Zengeya TA, Richardson DM (Eds) Frameworks used in Invasion Science. NeoBiota 62: 489-508. https://doi.org/10.3897/ neobiota.62.52664

\begin{abstract}
Biological invasions are inextricably linked to how people collect, move, interact with and perceive nonnative species. However, invasion frameworks generally do not consider reciprocal interactions between non-native species and people. Non-native species can shape human actions via beneficial or detrimental ecological and socioeconomic effects and people, in turn, shape invasions through their movements, behaviour and how they respond to the collection, transport, introduction and spread of non-natives. The feedbacks that stem from this 'coupled human and natural system' (CHANS) could therefore play a key role in mitigating (i.e. negative feedback loops) or exacerbating (i.e. positive feedback loops) ongoing and future invasions. We posit that the invasion process could be subdivided into three CHANS that span from the source region from which non-natives originate to the recipient region in which they establish and spread. We also provide specific examples of feedback loops that occur within each CHANS that have either reduced or facilitated new introductions and spread of established non-native species. In so doing, we add to exisiting invasion frameworks to generate new hypotheses about human-based drivers of biological invasions and further efforts to determine how ecological outcomes feed back into human actions.
\end{abstract}

\section{Keywords}

coupled human and natural systems, coupled social-ecological systems, feedback loop, invasive, negative feedback, non-native, positive feedback 


\section{Introduction}

Humans are the principal drivers of biological invasions (see the Glossary in Box 1 for the definition of 'invasive'), evinced by the much higher rate of invasions in the modern era (Ricciardi 2007) and the wealth of literature detailing how people aid the establishment and spread of non-native species (e.g. Suarez et al. 2001; Wilson et al. 2009; Capinha et al. 2015). The invasion process could, therefore, be considered as a 'coupled human and natural system' (CHANS; defined by Liu et al. 2007) because natural components (i.e. non-native species and the environments or communities they impact) interact with and are affected by human behaviour and socioeconomic activity. However, none of the major hypotheses in invasion ecology (summarised by Catford et al. 2009) and few conceptual frameworks of the invasion process (e.g. Richardson et al. 2000; Colautti et al. 2006; Blackburn et al. 2011) explicitly considers reciprocal feedbacks (hereafter termed 'feedback loops') between humans and non-native species

Box I. Glossary of terms.

Impact: Observable effects of non-native species, which can include ecological, economic and human health effects and changes in the provisioning of ecosystem services

Intentional: The intentional human-mediated transport and introduction of nonnatives, such as for horticulture, the pet trade or biocontrol

Invasive: A non-native species with demonstrable impacts

Negative feedback loop: A human-natural feedback that continually stabilises or reduces ongoing or future invasions (also known as a 'balancing' feedback loop)

Non-native: Species moved outside their native range by human actions

Positive feedback loop: A human-natural feedback that continually increases ongoing or future invasions (also known as 'exacerbating' or 'reinforcing' feedback loops)

Recipient region: The specific location or region into which non-natives are introduced

Source region: The specific location or region from which a non-native originates

Unintentional: Non-natives whose human-mediated transport and introduction is entirely accidental, such as via hitchhiking on vehicles or through constructed corridors 
(but see Lodge et al. 2009; Howard 2019). Feedback loops are a distinguishing feature of CHANS because they are indicative of two, fully linked systems in which one system both drives and responds to changes in the other. These types of human-ecological feedback loops often produce unexpected interactive effects, such as sudden threshold shifts or lagged responses (Parker et al. 2008; Kramer et al. 2017). If these feedback loops exist for biological invasions, then identifying and incorporating them within invasion frameworks is essential to understanding how people can slow invasion rates, reduce negative invader impacts or accelerate stages of the invasion process.

We posit that three CHANS feedback loops can manifest within different stages of the invasion process, spanning from the initial source region where non-native species originate to the recipient region where non-natives establish and spread (Fig. 1). Each of these CHANS can produce 'negative' feedback loops that slow the rate of new species invasions over time and 'positive' feedback loops that accelerate invasion rates or exacerbate the impacts of previously-established invasive species (see examples in Fig. 2). Explicitly recognising the potential for multiple socioecological feedback loops within the invasion process elevates the relevance of existing published evidence that humans play a strong role in invasions. Additionally, recognising CHANS within the invasion process shifts the role of humans away from being simply vectors or unidirectional interactors with ecosystems that prime the way for invasions (Gurevitch and Padilla 2004) to one where people and non-native species are continually experiencing reciprocal feedback interactions in ways that can further control, sustain or even magnify invasion rates.

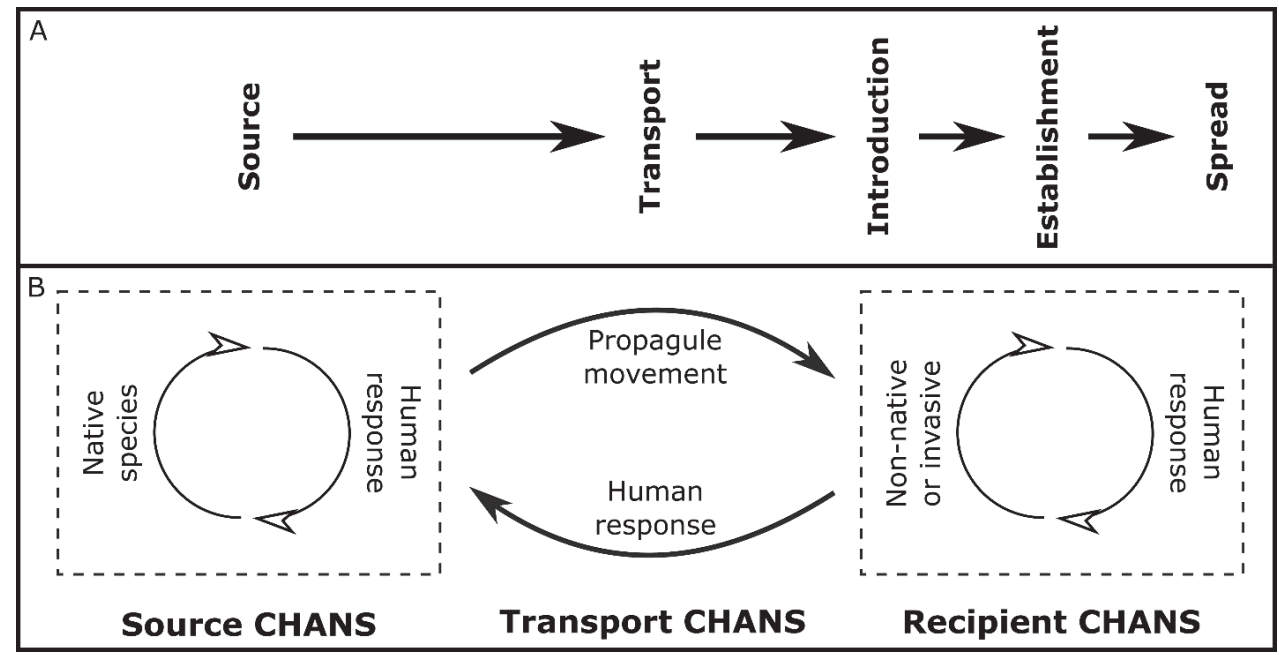

Figure I. Comparison of (A) the different stages of the invasion process (based on Colautti et al. 2006) to (B) the three, linked coupled human-natural systems (CHANS) that potentially overlap these stages. The 'Source' CHANS encompassess the response of people in the region from which non-natives originate (i.e. the human system) to changes in and the collection of their own native biodiversity (i.e. the natural system). The 'Recipient' CHANS captures interactions between people and the introduction, establishment and spread of non-natives. The 'Transport' CHANS links the response of people to non-natives in the recipient region to the ongoing and future transport of organisms from the source region. 
The first of our three CHANS (the 'source' coupling; Fig. 1A) acknowledges that there are human-natural feedback loops entirely localised within the region from which non-native species are sourced. Source region feedback loops can determine which and how many organisms are collected and transported to a new location (the 'recipient' region). Here, the CHANS is driven by how people in the source region perceive and respond to their local biodiversity, particularly in terms of the availability of species to exploit in trade. This feedback loop also recognises that local environmental or trade regulations can profoundly influence the quantity and diversity of species that enter the invasion process. These regulations may either prohibit the intentional transport of potentially invasive species or limit activities that tend to unintentionally transport individuals of species that may be invasive.

The second feedback loop (the 'transport' coupling; Fig. 2) encompasses interactions between source and recipient regions resulting from the transport of non-native species. Introduced non-native species can influence the ecology, culture, policy, economics or human health of the recipient region. These effects can then feed back to the source

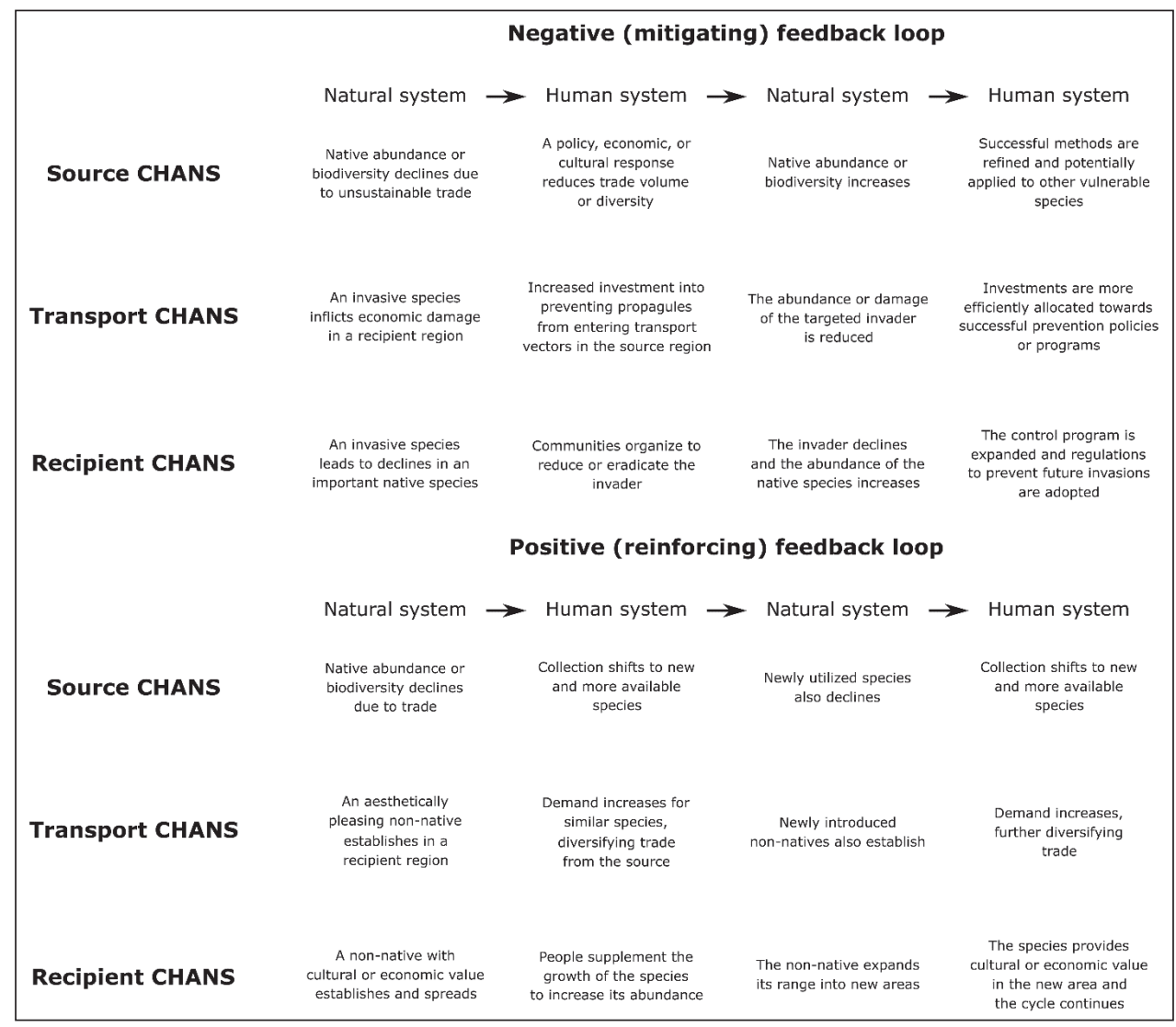

Figure 2. Examples of potential negative and positive feedback loops. Negative feedback loops can mitigate or balance invasions, whereas positive feedback loops can reinforce or exacerbate invasions. Examples are presented for each of the three proposed CHANS (source, transport, and recipient; Fig. 1) involved in the invasion process and are discussed further in the text. 
region, such as through new prevention policies or shifting consumer demand. The transport feedback loop can span global scales, driven by inter-country travel and trade, but can also include local-scale interactions within a single region, provided propagules are being moved outside their native range (Faulkner et al. 2020; Pergl et al. 2020).

The final CHANS (the 'recipient' coupling; Fig. 2) encompasses local-scale feedbacks in the recipient region between humans and the effects of established non-native or spreading invasive species. This CHANS emphasises that how people respond to non-native populations and associated impacts in the recipient region is driven by local culture, demographics and economics, as well as the traits of the non-native species themselves. The response of local people can be a key driver for mitigating or further exacerbating potential new introductions, as well as promoting or preventing the continued spread of already-established non-native species.

In what follows, we highlight literature that supports key aspects of these three couplings and outline examples that show how human-nature linkages at each of these invasion stages can create both negative and positive feedback loops.

\section{Source coupling}

\section{Drivers of source feedback loops}

Invasion feedback loops that originate from the source coupling are driven by how people in the source region (i.e. the human system) respond to changes in that region's native species (i.e. the natural system) and how native species are, in turn, affected by these human responses. The key consideration in the source CHANS is whether these human-natural couplings can act to mitigate or exacerbate the rate at which the source region's native species are transported to one or more regions as non-natives.

\section{Source region negative feedbacks}

Source region negative feedback loops slow the rate of transport of non-native species into one or more recipient regions. The clearest examples of such feedbacks are locally-instituted quotas or harvest bans associated with the trade of live animals or plants. These top-down
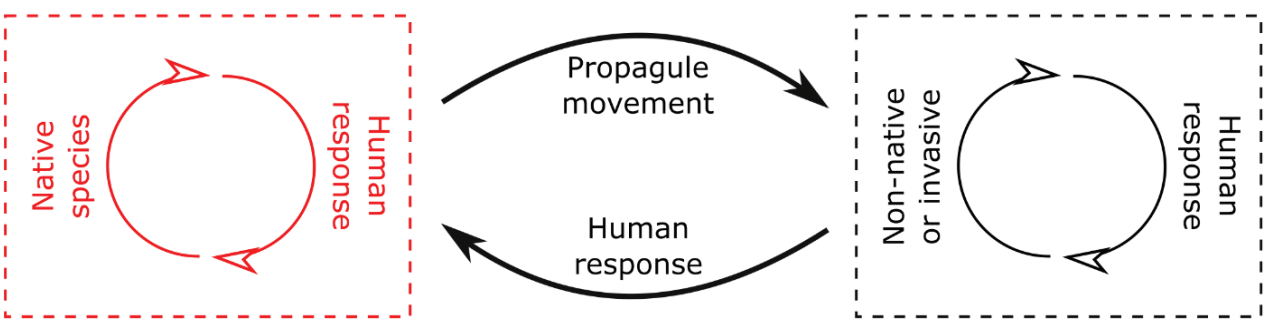

Scheme I. 
regulatory measures are a human response to declining native species abundances that can reduce the exportation rate of the source region's native species (e.g. Rabemananjara et al. 2008). These measures reduce the diversity of species transported as non-natives or the propagule pressures associated with any one of these transported species. This feedback would, however, only form a complete loop if these regulations lead to an increase in the abundance or overall biodiversity of species native to the source region. If so, an additional strengthening of regulations or the adoption of new ones may follow (e.g. building 'legitimacy' in resource management; Pinkerton and John 2008), which may further slow the rate of organism collection and transport. A similar negative feedback loop can occur via bottom-up community interventions to conserve biodiversity by reducing unsustainable or illegal native species collection practices (Cooney et al. 2017). For example, by voluntarily reducing trade to protect a source region's biodiversity or to ensure sustainable trade, the number of species transported as non-natives out of a source location will slow and successful programmes could lead to the refinement or adoption of further interventions.

Negative feedback loops may also arise when people or agencies in the source region become more aware that their native species are considered invasive elsewhere. In this instance, people in the source region respond of their own volition by reducing the intentional or unintentional transport of known invaders. If the impacts of invasion are well-understood or economic incentives are provided to reduce the collection or accidental transport of known invaders out of the source region, the result could be improved detection and removal of hitchhikers before transport or a shift towards trading less harmful species. Cooperative international trade agreements that seek to reduce the further spread of known-invasive species, such as those contained within the International Plant Protection Convention or the Ballast Water Management Convention, embody this shift in international trade and reduction of hitchhikers. Cooperative international trade agreements encourage member nations to commit to actions that reduce the chances that vectors that emanate from their country transport invasive species to others (Keller and Perrings 2011). In this context, a negative feedback loop can result if the removal programmes or types of behaviour enacted in the source region succeed in reducing the number or diversity of transported organisms and these successes, in turn, provide information to reinforce or refine future efforts.

\section{Source region positive feedbacks}

Positive feedback source loops result in a continual increase in the quantity or diversity of species native to the source region being transported as non-natives to recipient regions. For example, similar in practice to 'fishing down the food web' (Pauly et al. 1998), if people in the source region respond to declines in their native species by continually shifting the base of exploitation to supply the live-animal or plant trade with the next most abundant or easily accessed species (Harfoot et al. 2018), then their actions ensure a continual increase in the pool of native species transported to recipient regions as non-natives. The same type of feedback loop can result from regulations in the source region that inhibit the collection or use of their declining native species if it drives com- 
mercial diversification towards the exploitation of new native species (e.g. Schroth and Ruf 2014). The loop continues if the abundances of newly-exploited species also decline, requiring new protective regulations which could again shift trade towards new species.

With the creation or continuation of a positive feedback loop for species that are intentionally transported, the resulting diversification in the native species transported from a source region will also diversify the transport of hitchhiking organisms associated with these species (e.g. the increasing diversity of zoonotic diseases as the global wildlife trade expands; Chomel et al. 2007). Beyond this example, however, it seems unlikely that positive feedback loops could arise for unintentionally collected organisms, such as plant seeds on clothing or arthropods within wooden pallets. Such feedbacks seem implausible given that people in the source region would have to purposefully increase their ability or propensity to collect and transport such species unintentionally based on changes in local biodiversity.

\section{Transport coupling}

\section{Drivers of transport feedback loops}

There is a well-established association between trade and travel intensity from source to recipient regions and the rate at which non-native species accumulate within recipient regions (Perrings et al. 2005; Hulme 2009; Seebens et al. 2017; Pyšek et al. 2020). A feedback loop can arise in this context if the effects of non-native species in the recipient region drive changes in policy, economics or human behaviour so that trade and travel from the source region either decreases (negative loop) or increases (positive loop). These feedbacks result in a concomitant reduction or acceleration of non-native introduction diversity or rates to the recipient region.

\section{Transport negative feedbacks}

Negative transport feedback loops occur when the economic, ecological or cultural costs of invasions in the recipient region incite a human response that reduces the diversity or quantity of species transported out of the source region. A full feedback loop results when this response is then adapted based on how effectively it prevented further
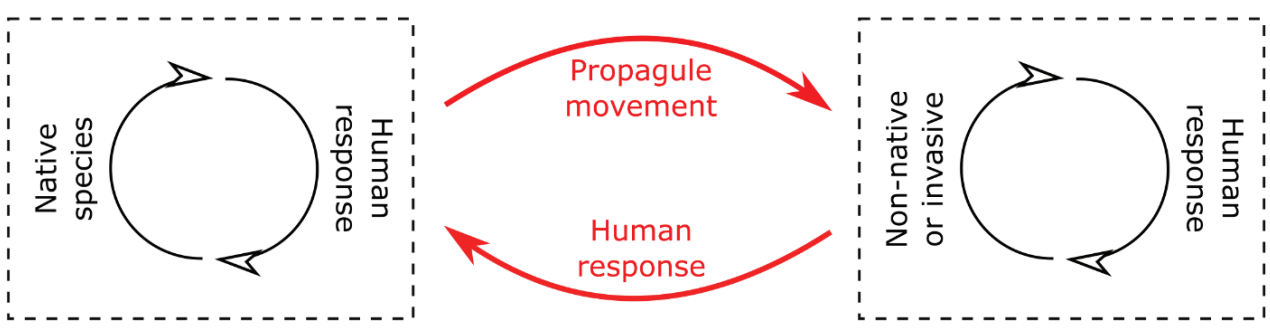

Scheme 2. 
invasions or invader effects. For example, the damage caused by multiple invasive species in New Zealand led to government adoption of strict biosecurity measures that limit the importation of novel non-native species from a variety of source regions (Jay et al. 2003). These measures, in turn, prompted industry and government agencies in source regions to impose or strengthen their own pre- or within-transport biosecurity measures, such as adoption of cargo or ballast treatment, so that their products can successfully pass border inspections. The feedback loop was completed when these regulations or incentives were further revised, depending upon whether non-native establishment and spread declined or when a new invader arose (Hayden and Whyte 2003).

Economic feedbacks from the recipient region could also affect non-native species transport if the damage caused by an invader shifts investments towards funding prevention methods that reduce the quantity or diversity of propagules that enter, survive or exit transport vectors (Lodge et al. 2009; Latombe et al. 2020). This feedback loop hinges on the relative costs and benefits of investing in measures that prevent initial introduction compared to focusing on control of already established non-natives or even not managing the invasion process at all. Biosecurity preventative measures could be favoured if, for instance, the costs of pre-introduction treatments are low (Hyytiäinen et al. 2013), the projected or known damage of an invader is high (Marbuah et al. 2014) and if policy-makers are willing to accept the uncertainties of preventing potential invaders over controlling known invaders (Finnoff et al. 2007). There is also a clear potential for a shift in the strength of this negative feedback loop over time. Prevention can be favoured if damage increases as an invasive species' population increases or could be disfavoured if the invasive population declines. New technologies or refined risk assessments (e.g. Kumschick et al. 2020) could also alter the perceived costs versus benefits of investing in preventing non-native transport.

Awareness campaigns or stigmatising trade in particular species (Fischer 2004) provides an alternative type of cultural negative feedback loop that can reduce demand for live species or products that commonly result in the establishment of non-native species in the recipient region. Consumer preferences in the recipient region are a key driver of both intentional trade and unintentional transport of non-native species (Sinclair et al. 2020). Campaigns that target consumers of goods associated with high rates of species invasion can therefore reduce the diversity or volume of species transported from a source region, such as by altering preferences to favour native or non-invasive species (e.g. Drew et al. 2010; Patoka et al. 2018) or by encouraging the use of more sustainable or locally-sourced goods (e.g. Barlow et al. 2014). However, it is unclear whether changes in consumer demand can, in turn, be affected by elevated rates in the introduction and establishment of non-native species, thus completing the full feedback loop. Such a feedback loop might occur if consumer demand continues to decline in response to the success of awareness programmes at controlling non-native introduction rates.

\section{Transport positive feedbacks}

Non-native species introductions and subsequent invasion impacts in a recipient region can drive socioeconomic- or policy-based feedback loops that continually increase 
non-native species transport out of source regions over time. Increasing introductions of non-native pets and horticultural plants, for example (Mack 2003; Lockwood et al. 2019), has served to increase consumer demand for such products. This increased demand has subsequently elevated trade volume and diversified the number of species within these trades (e.g. Drew et al. 2010; Seebens et al. 2017; Scheffers et al. 2019), creating a potential feedback loop. A similar feedback could result from biocontrol introductions in which the human response to the effects of a non-native species is to introduce another non-native, natural enemy, which could subsequently become invasive and require further control (Simberloff and Stiling 1996). Culturally-driven import and release of traditional live food plants and animals by human communities (e.g. snakehead fish; Cagauan 2007) could also create a positive feedback loop in which the initial successful introduction of desired non-native species to re-create a cultural 'sense of place' can increase the appeal of further introductions (Brook 2003). All of these examples of potential positive feedback loops can produce a socioeconomic version of invasional meltdown (invasive species facilitating further invasions; Simberloff and Von Holle 1999), whereby the human response to non-native species introductions or the effects of these introductions is to desire that more non-native species be introduced, which could in turn spur further introductions (Fig. 3).

Regulation can also create positive feedback loops if the response of the people living in a source region to a policy change enacted in the recipient region is avoidance, rather than compliance. Avoidance behaviour can expand transport into new regions, subsequently increasing the spatial dispersion of transport vectors and thus associated introductions of non-native species. An agent-based model by Ameden et al. (2009) provides an example of such avoidance by showing that importers might respond to increases in invasive species border inspections with 'port-shopping' behaviour by seeking out ports with lower inspection standards. Non-native species blacklists can similarly drive avoidance responses by shifting transport towards as-yet unlisted taxa, subsequently increasing the probability of introducing new non-native species in recipient locations (García-de-Lomas and Vilà 2015). There are also examples in which travel fees in recipient regions can alter human movements rather than prevent or control them (e.g. Chivers et al. 2017) and this same principle could apply to transport vectors travelling between source and recipient regions. A full positive feedback loop can then arise when regulatory efforts subsequently expand to encompass the new regions into which vectors are now travelling, creating an 'arms race' between regulatory policy and avoidance responses.

\section{Recipient region coupling}

\section{Drivers of recipient feedback loops}

Once non-native species establish within a recipient region, the population abundance or geographical distribution of these species can be reduced or augmented via our final CHANS feedback loop. Here, reciprocal loops are generated by the cultures within a 


\section{Socioeconomic invasion meltdown (positive feedback loop)}

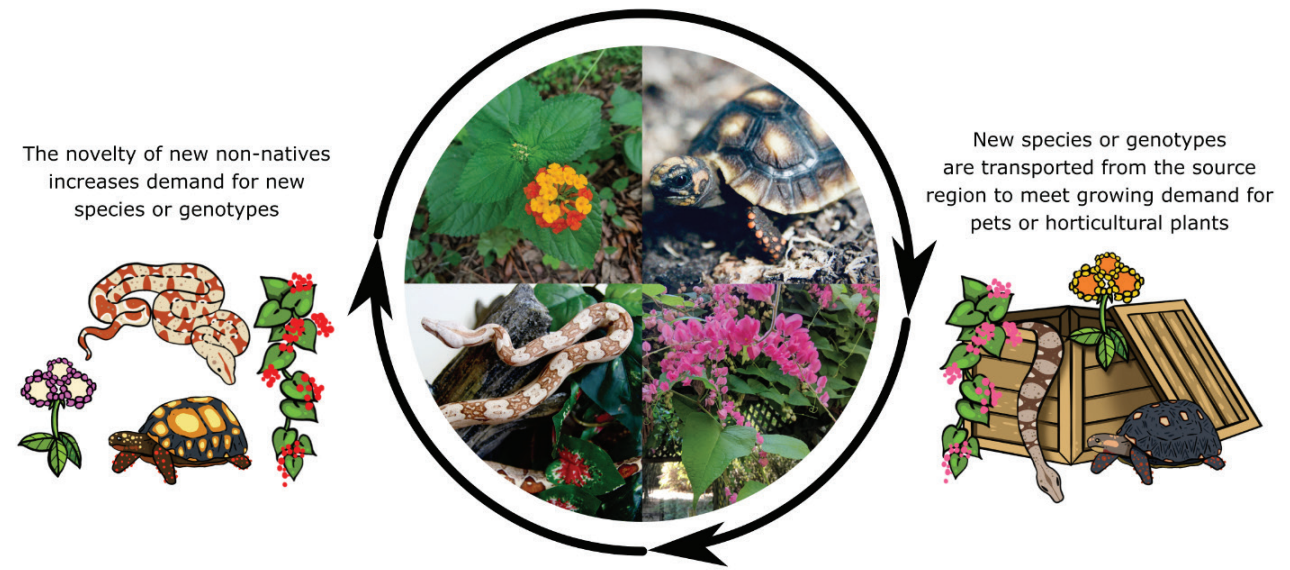

The new non-natives are introduced to

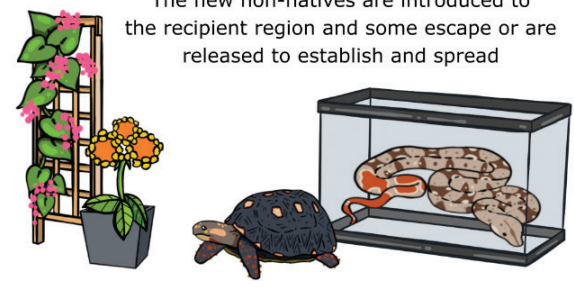

Figure 3. A conceptualisation of an invasion positive feedback loop driven by intentional introductions of non-native species for the horticulture or pet trades. The example species used are, from the top left of the centre photograph and moving clockwise, Lantana (Lantana camara), the red-footed tortoise (Chelonoidis carbonarius), coral vine (Antigonon leptopus) and the red-tailed boa (Boa constrictor). Each species has a history of intentional introduction and successful establishment in recipient regions. Drawings with different colours are based on actual colour varieties or morphs of these species. The plant photographs were provided by James Sinclair (the first author), the animal photographs were provided by Keara Clancy (Department of Wildlife Ecology and Conservation at the University of Florida) and the drawings were commissioned from Marie-Josée Létourneau for use in this manuscript.

recipient region and the perceptions of risks and benefits that established non-native species present (Trigger 2008; Gaertner et al. 2017; Vimercati et al. 2017; Polák et al. 2019; Potgeiter and Cadotte 2020). These perceptions will feed back towards either inhibiting or accelerating the population growth rate, geographical range expansion and/or secondary spread of established non-native species and, thus, their impacts which, in turn, will affect how the non-native is perceived (Shackleton et al. 2019).

\section{Recipient region negative feedbacks}

Non-native species that cause ecological or economic damage or that disrupt cultural and recreational activities can instigate a negative feedback loop via instigating control or eradication efforts or incentivising the use of native species or products that do not 

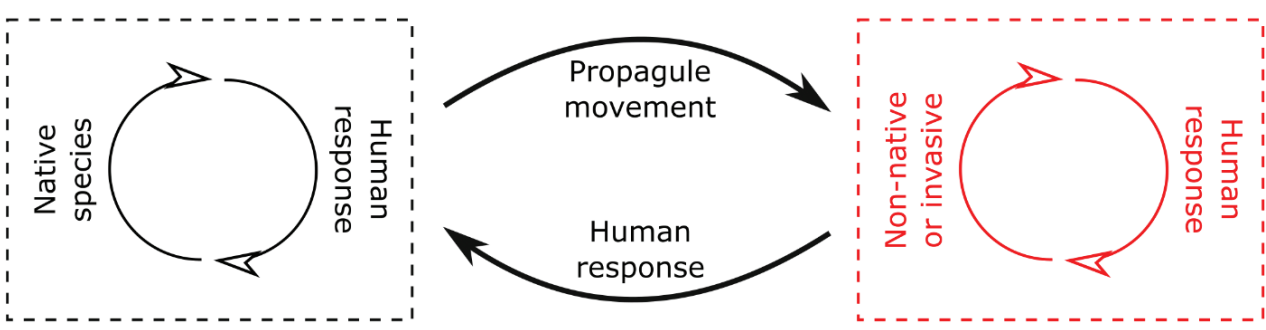

Scheme 3.

facilitate secondary spread of non-native species. A full negative feedback loop occurs if self-, community- or government-enforced initiatives against harmful non-native species successfully limits their abundance or distribution or promotes awareness that facilitates management and reduces further spread (e.g. Klapwijk et al. 2016). These successes are then used to refine or inspire future efforts (e.g. Simberloff 2009). In this way, the human system is continually responding to ongoing changes in the natural system to better balance or mitigate invasions. An example of this feedback loop is when invasive trees or grasses restrict homeowner site lines or invasive aquatic plants limit boating and fishing opportunities and individual homeowners respond by actively reducing the population abundance of the non-native on their property (Charles and Dukes 2007; Niemiec et al. 2017). Invasive species can also pose risks to the persistence of culturally-valuable native species, such as the risk that the invasive emerald ash borer will result in the near-total loss of native ash trees that feature in the origin of stories about Native American tribes (Poland et al. 2017). When such damage to cultural or aesthetic amenities occurs, there is often a strong desire by residents to restore a 'natural' aesthetic by managing the invasive species or imposing stricter regulation of invasive and non-native species use or related goods (Dickie et al. 2014; Kueffer and Kull 2017). These individual responses can create full feedback loops when communities organise to form self-promoting groups to control several non-native species. Often membership in these groups or the social acknowledgement people receive from these groups, leads to more individuals joining, thus creating a social expectation of further engagement in non-native species management (Niemiec et al. 2016). This feedback can be reinforced when community groups exert considerable pressure on local governments to initiate management actions, which often happens due to local media attention or when the communities feel the potential threat of a growing invasion (Crowley et al. 2017).

\section{Recipient region positive feedbacks}

Many non-native species can elicit sympathetic reactions from people who have a historical relationship with these taxa or who are not aware of the issues presented by invasive species. Non-natives can also become more positively perceived through time as people may view pest species positively or novel if population sizes decline (Shackleton et al. 2019) and fear 
of non-natives can decrease with increased familiarity to the damage they can cause (Schüttler et al. 2011). Sympathetic or positive reactions to established non-native species can drive their increased population growth rates or enhanced dispersal potential via the human desire for their further establishment and spread. These actions can, in turn, expose new people to the non-native species and reinforce secondary spread through positive associations with the non-native, creating a positive feedback loop. For example, people in many regions have intentionally introduced non-native species for aesthetic or cultural purposes and, in some cases, these species have become culturally significant, resulting in a cultural desire for continued population growth or range expansion of the non-native species $(\mathrm{Nu}-$ nez and Simberloff 2005). Due to this connection, non-native species that may be economically detrimental, but elicit sympathy through the human-animal bond (e.g. deer) or have charismatic features, such as song or colouration, may enjoy little to no reductions in their individual survival or reproduction rates due to push-back from citizens to proposed control measures (e.g. common lionfish; Jimenez et al. 2017). In fact, for many such species, people will actively promote survival and spread rates of non-natives through supplemental feeding and other protection (Robinson et al. 2005; Bonter et al. 2010). Even with invasive species, particularly horticulture plants introduced for aesthetics that have significant ecological impacts but limited negative or positive economic impacts (e.g. bamboo and tallow tree), invasive populations may be spread prolifically through continued local transport and intentional planting or release. This feedback occurs because, as populations of these invasive species spread, more people encounter the species which, in turn, fosters the desire for people to further the species' spread via intentional planting (e.g. Bradley et al. 2010).

Positive feedback loops can also occur when an invader becomes integrated with human communities in the recipient region as a resource (Robinson et al. 2005; dos Santos et al. 2014; Vilá and Hulme 2017), subsequently leading to human actions that promote further spread or that oppose control or eradication efforts. Many non-native species, for instance, have become key targets for hunting or provide essential food sources for local communities (Jean Desbiez et al. 2011). In several such circumstances, traditionallyhunted native species have declined as a result of past over-exploitation or the ecological impacts of other invasive species, resulting in a cultural shift in hunting practices towards exploitation of a non-native (Robinson et al. 2005; Jean Desbiez et al. 2011). Over time, responding to ongoing declines in native species by continually spreading a non-native, may become the cultural norm and the perception of the new species as 'non-native' may be lost (Semenya et al. 2012; Shackleton et al. 2015). People may also facilitate the secondary spread of established and valuable non-natives to new areas in response to its growing value as a resource (Nuñez et al. 2012), creating a full feedback loop.

Lastly, management responses to non-natives that do not account for human behaviour could drive positive feedback loops through an arms race between regulation and non-compliance. These types of feedbacks are more thoroughly discussed in the source and transport CHANS sections above, so we will not delve into them too deeply again, but it is important to acknowledge their localised role in the recipient region. Examples of potential positive feedbacks include access or cleaning fees levied to reduce unintentional non-native spread, which can instead drive the secondary spread of non-natives into new locations (Chivers et al. 2017). Similarly, localised restrictions on the sale or purchase of non-native 
species can drive customers to seek out nearby, unregulated vendors (e.g. shifting the withinstate US trade of horticultural plants to out-of-state sources; Maki and Galatowitsch 2004). Efforts aimed at collecting non-natives from the broader public, such as pet or plant surrender programmes, could also perversely cause non-native species releases if people do not perceive participation to be personally cost effective or convenient (Drake et al. 2015). These examples can become fully realised positive feedback loops if the result of the human response is an increase in non-native species establishment, spread or impacts which, in turn, drives the adoption of further management responses that are again avoided.

\section{Implications for Invasion Science}

There is extensive literature on human responses to non-native and invasive species, but rarely are feedback loops within or across invasion stages explicitly considered (cf. Lodge et al. 2009; Howard 2019; and Hulme et al. 2020 for parallels with epidemiology). The recognition that three distinct CHANS can occur across the invasion process and that each can create negative and positive feedback loops, provides three key insights to invasion science.

Firstly, a CHANS perspective highlights that recipient region invasions are inextricably linked to interactions with the source region and that human-nature feedbacks, localised solely within the source, can drive invasion dynamics. This is a key insight because many invasion frameworks overlook processes that occur prior to non-native species introduction as potential drivers of accelerating global invasion rates (Sinclair et al. 2020). Considering how policy, economic and cultural feedback loops within the source region subsequently affect the invasion process and human-nature interactions in the recipient region could therefore be crucial for predicting how introductions may change in the future and for improving invader management (i.e. the same implications of a better focus on the 'supply-side' of invasions discussed by Verling et al. 2005).

Secondly, the continual feedback between people and native or non-native species in the CHANS we have outlined could produce unexpected or unpredictable interactions that may continue to change over time as humans respond and adapt to the presence of nonnative species. These types of emergent effects are discussed more fully in other literature (e.g. CHANS or social-ecological systems; Liu et al. 2007; Preiser et al. 2018) and include: (i) legacy or lagged responses; (ii) thresholds and resiliency between alternate states; and (iii) indirect effects. Though not discussed from a CHANS perspective, there is evidence that these types of interactions can manifest in the invasion process. Examples include current invasions that are a legacy of past human-nature interactions (Essl et al. 2011), introductions that drive regime shifts in how people interact with non-native species (Shackleton et al. 2018), and indirect human responses to non-natives of changing demand for goods or services rather than direct control of local populations (Drew et al. 2010). This potential for complex and surprising human-nature interactions in invasions highlights a need to re-examine (and potentially revise) current hypotheses about the major drivers of invasion rates to address how humans might be shaping the ecological processes involved. Efforts to understand invasions that lack a consideration of human components will in- 
crease the likelihood that surprising, interactive effects will arise (Pyšek et al. 2020) and interventions, based on such incomplete knowledge, could generate new problems or even exacerbate invasions (e.g. control policies that drive a positive feedback loop).

Thirdly and finally, the potential existence of the three CHANS we have outlined highlights that there is still a great deal we do not know about how people and non-native species interact. Many of the example feedback loops we reviewed are theorised, simplified representations of complex interactions. We have supported our ideas where we can with background literature, but there is simply not enough research to fully specify the complete feedback loop for any one example. Further work is thus required to confirm that these CHANS exist as we have outlined and, if so, to fill in the complexities within each. Examples of such complexities include potential variability in the strength and relevance of each CHANS amongst different types of intentional and unintentional invasion pathways (e.g. intentionally released versus escaped non-natives; Hulme 2009). Feedback relevance may also shift across stages of the invasion process, such as accidental escapees or hitchhikers that are initially affected by policy or economic feedbacks, but cultural feedbacks may become more relevant as people become aware of the invader's impacts in the recipient environment. The prevalence of the non-native species-to-people portion of invasion feedback loops is also potentially complex. Examples of one-way feedbacks in which people respond to non-native species abound in the invasion literature (e.g. intentional introductions to encourage establishment or eradication programmes to remove spreading invaders), but less is known about how readily this human response is affected by subsequent changes in the non-native species themselves (but see examples in Howard 2019). Therefore, while our approach serves to deepen continuing efforts in invasion science and ecology as a whole to better account for the role of humans in natural processes, we have only scratched the surface of the milieu of potential interactions that likely exist between people and non-native species.

\section{Acknowledgements}

We would like to thank Marie-Josée Létourneau and Keara Clancy for providing the artwork or photographs used in Fig. 3 and for agreeing to their publication. This paper emerged from a workshop on 'Frameworks used in Invasion Science' hosted by the DSI-NRF Centre of Excellence for Invasion Biology in Stellenbosch, South Africa, 11-13 November 2019, that was supported by the National Research Foundation of South Africa and Stellenbosch University. Additionally, part of this work is supported by the National Science Foundation under grant number DEB-1832016, Central Arizona-Phoenix Long-Term Ecological Research Program (CAP LTER).

\section{References}

Ameden HA, Boxall PC, Cash SB, Vickers DA (2009) An agent-based model of border enforcement for invasive species management. Canadian Journal of Agricultural Economics/Revue canadienne d'agroeconomie 57: 481-496. https://doi.org/10.1111/j.1744-7976.2009.01166.x 
Barlow L-A, Cecile J, Bauch CT, Anand M (2014) Modelling interactions between forest pest invasions and human decisions regarding firewood transport restrictions. PLoS ONE 9(4): e90511. https://doi.org/10.1371/journal.pone.0090511

Blackburn TM, Pyšek P, Bacher S, Carlton JT, Duncan RP, Jarošík V, Wilson JRU, Richardson DM (2011) A proposed unified framework for biological invasions. Trends in Ecology \& Evolution 26: 333-339. https://doi.org/10.1016/j.tree.2011.03.023

Bonter DN, Zuckerberg B, Dickinson JL (2010) Invasive birds in a novel landscape: habitat associations and effects on established species. Ecography 33: 494-502. https://doi.org/10.1111/ j.1600-0587.2009.06017.x

Bradley BA, Blumenthal DM, Wilcove DS, Ziska LH (2010) Predicting plant invasions in an era of global change. Trends in Ecology \& Evolution 25: 310-318. https://doi.org/10.1016/j. tree.2009.12.003

Brook I (2003) Making here like there: place attachment, displacement and the urge to garden. Ethics, Place\&Environment6:227-234.https://doi.org/10.1080/1366879042000200651

Burt JW, Muir AA, Piovia-Scott J, Veblen KE, Chang AL, Grossman JD, Weiskel HW (2007) Preventing horticultural introductions of invasive plants: potential efficacy of voluntary initiatives. Biological Invasions 9: 909-923. https://doi.org/10.1007/s10530-007-9090-4

Cagauan AG (2007) Exotic aquatic species introduction in the Philippines for aquaculture - A threat to biodiversity or a boom to the economy. Journal of Environmental Science and Management 10: 48-62.

Capinha C, Essl F, Seebens H, Moser D, Pereira HM (2015) The dispersal of alien species redefines biogeography in the Anthropocene. Science 348: 1248-1251. https://doi. org/10.1126/science.aaa8913

Catford JA, Jansson R, Nilsson C (2009) Reducing redundancy in invasion ecology by integrating hypotheses into a single theoretical framework. Diversity and Distributions 15: 22-40. https://doi.org/10.1111/j.1472-4642.2008.00521.x

Charles H, Dukes JS (2007) Impacts of invasive species on ecosystem services. In: Nentwig W (Ed.) Biological Invasions. Springer Berlin Heidelberg, Berlin, Heidelberg, 217-237. https://doi.org/10.1007/978-3-540-36920-2_13

Chivers C, Drake DAR, Leung B (2017) Economic effects and the efficacy of intervention: exploring unintended effects of management and policy on the spread of non-indigenous species. Biological Invasions 19: 1795-1810. https://doi.org/10.1007/s10530-017-1391-7

Chomel BB, Belotto A, Meslin FX (2007) Wildlife, exotic pets, and emerging zoonoses. Emerging Infectious Diseases 13: 6-11. https://doi.org/10.3201/eid1301.060480

Colautti RI, Grigorovich IA, MacIsaac HJ (2006) Propagule pressure: a null model for biological invasions. Biological Invasions 8: 1023-1037. https://doi.org/10.1007/s10530-005-3735-y

Cooney R, Roe D, Dublin H, Phelps J, Wilkie D, Keane A, Travers H, Skinner D, Challender DWS, Allan JR, Biggs D (2017) From poachers to protectors: engaging local communities in solutions to illegal wildlife trade. Conservation Letters 10: 367-374. https://doi. org/10.1111/conl.12294

Crowley SL, Hinchliffe S, McDonald RA (2017) Conflict in invasive species management. Frontiers in Ecology and the Environment 15: 133-141. https://doi.org/10.1002/fee.1471

Dickie IA, Bennett BM, Burrows LE, Nuñez MA, Peltzer DA, Porté A, Richardson DM, Rejmánek M, Rundel PW, van Wilgen BW (2014) Conflicting values: ecosystem services and invasive tree management. Biological Invasions 16: 705-719. https://doi.org/10.1007/s10530-013-0609-6 
dos Santos LL, do Nascimento ALB, Vieira FJ, da Silva VA, Voeks R, Albuquerque UP (2014) The cultural value of invasive species: a case study from semi-arid northeastern Brazil. Economic Botany 68: 283-300. https://doi.org/10.1007/s12231-014-9281-8

Drake DA, Mercader R, Dobson T, Mandrak N (2015) Can we predict risky human behaviour involving invasive species? A case study of the release of fishes to the wild. Biological Invasions 17: 309-326. https://doi.org/10.1007/s10530-014-0729-7

Drew J, Anderson N, Andow D (2010) Conundrums of a complex vector for invasive species control: a detailed examination of the horticultural industry. Biological Invasions 12: 2837-2851. https://doi.org/10.1007/s10530-010-9689-8

Essl F, Nehring S, Klingenstein F, Milasowszky N, Nowack C, Rabitsch W (2011) Review of risk assessment systems of IAS in Europe and introducing the German-Austrian Black List Information System (GABLIS). Journal for Nature Conservation 19: 339-350. https://doi.org/10.1016/j.jnc.2011.08.005

Faulkner KT, Hulme PE, Pagad S, Wilson JRU, Robertson MP (2020) Classifying the introduction pathways of alien species: are we moving in the right direction? In: Wilson JR, Bacher S, Daehler CC, Groom QJ, Kumschick S, Lockwood JL, Robinson TB, Zengeya TA, Richardson DM (Eds) Frameworks used in Invasion Science. NeoBiota 62: 143-159. https://doi.org/10.3897/neobiota.62.53543

Finnoff D, Shogren JF, Leung B, Lodge D (2007) Take a risk: preferring prevention over control of biological invaders. Ecological Economics 62: 216-222. https://doi.org/10.1016/j. ecolecon.2006.03.025

Fischer C (2004) The complex interactions of markets for endangered species products. Journal of Environmental Economics and Management 48: 926-953. https://doi.org/10.1016/j. jeem.2003.12.003

Gaertner M, Wilson JRU, Cadotte MW, MacIvor JS, Zenni RD, Richardson DM (2017) Non-native species in urban environments: patterns, processes, impacts and challenges. Biological Invasions 19: 3461-3469. https://doi.org/10.1007/s10530-017-1598-7

García-de-Lomas J, Vilà M (2015) Lists of harmful alien organisms: are the national regulations adapted to the global world? Biological Invasions 17: 3081-3091. https://doi.org/10.1007/ s10530-015-0939-7

Gurevitch J, Padilla DK (2004) Are invasive species a major cause of extinctions? Trends in Ecology \& Evolution 19: 470-474. https://doi.org/10.1016/j.tree.2004.07.005

Harfoot M, Glaser SAM, Tittensor DP, Britten GL, McLardy C, Malsch K, Burgess ND (2018) Unveiling the patterns and trends in 40 years of global trade in CITES-listed wildlife. Biological Conservation 223: 47-57. https://doi.org/10.1016/j.biocon.2018.04.017

Howard PL (2019) Human adaptation to invasive species: a conceptual framework based on a case study metasynthesis. Ambio 48: 1401-1430. https://doi.org/10.1007/s13280-019-01297-5

Hulme PE (2009) Trade, transport and trouble: managing invasive species pathways in an era of globalization. Journal of Applied Ecology 46: 10-18. https://doi.org/10.1111/j.13652664.2008.01600.x

Hulme PE, Baker R, Freckleton R, Hails RS, Hartley M, Harwood J, Marion G, Smith GC, Williamson M (2020) The Epidemiological Framework for Biological Invasions (EFBI): an interdisciplinary foundation for the assessment of biosecurity threats. In: Wilson JR, Bacher S, Daehler CC, Groom QJ, Kumschick S, Lockwood JL, Robinson TB, Zengeya TA, Richardson DM (Eds) Frameworks used in Invasion Science. NeoBiota 62: 161-192. https://doi.org/10.3897/neobiota.62.52463 
Hyytiäinen K, Lehtiniemi M, Niemi JK, Tikka K (2013) An optimization framework for addressing aquatic invasive species. Ecological Economics 91: 69-79. https://doi. org/10.1016/j.ecolecon.2013.04.001

Jay M, Morad M, Bell A (2003) Biosecurity, a policy dilemma for New Zealand. Land Use Policy 20: 121-129. https://doi.org/10.1016/S0264-8377(03)00008-5

Jean Desbiez AL, Keuroghlian A, Piovezan U, Bodmer RE (2011) Invasive species and bushmeat hunting contributing to wildlife conservation: the case of feral pigs in a Neotropical wetland. Oryx 45: 78-83. https://doi.org/10.1017/S0030605310001304

Jimenez C, Andreou V, Hadjioannou L, Petrou A, Alhaija RA, Patsalou P (2017) Not everyone's cup of tea: public perception of culling invasive lionfish in Cyprus. Journal of the Black Sea/Mediterranean Environment 23: 38-47.

Keller RP, Perrings C (2011) International policy options for reducing the environmental impacts of invasive species. BioScience 61: 1005-1012. https://doi.org/10.1525/bio.2011.61.12.10 Klapwijk MJ, Hopkins AJM, Eriksson L, Pettersson M, Schroeder M, Lindelöw Å, Rönnberg J, Keskitalo ECH, Kenis M (2016) Reducing the risk of invasive forest pests and pathogens: combining legislation, targeted management and public awareness. Ambio 45: 223-234. https://doi.org/10.1007/s13280-015-0748-3

Kramer DB, Hartter J, Boag AE, Jain M, Stevens K, Nicholas KA, McConnell WJ, Liu J (2017) Top 40 questions in coupled human and natural systems (CHANS) research. Ecology and Society 22: 1-44. https://doi.org/10.5751/ES-09429-220244

Kueffer C, Kull CA (2017) Non-native Species and the aesthetics of nature. In: Vilà M, Hulme PE (Eds) Impact of biological invasions on ecosystem services. Springer, Berlin, 311-324. https://doi.org/10.1007/978-3-319-45121-3_20

Kumschick S, Wilson JRU, Foxcroft LC (2020) A framework to support alien species regulation: the Risk Analysis for Alien Taxa (RAAT). In: Wilson JR, Bacher S, Daehler CC, Groom QJ, Kumschick S, Lockwood JL, Robinson TB, Zengeya TA, Richardson DM (Eds) Frameworks used in Invasion Science. NeoBiota 62: 213-239. https://doi.org/10.3897/neobiota.62.51031

Essl F, Latombe G, Lenzner B, Pagad S, Seebens H, Smith K, Wilson JRU, Genovesi P (2020) The Convention on Biological Diversity (CBD)'s Post-2020 target on invasive alien species - what should it include and how should it be monitored? In: Wilson JR, Bacher S, Daehler CC, Groom QJ, Kumschick S, Lockwood JL, Robinson TB, Zengeya TA, Richardson DM (Eds) Frameworks used in Invasion Science. NeoBiota 62: 99-121. https://doi.org/10.3897/neobiota.62.53972

Liu J, Dietz T, Carpenter SR, Folke C, Alberti M, Redman CL, Schneider SH, Ostrom E, Pell AN, Lubchenco J, Taylor WW, Ouyang Z, Deadman P, Kratz T, Provencher W (2007) Coupled human and natural systems. AMBIO: A Journal of the Human Environment 36: 639-649. https://doi.org/10.1579/0044-7447(2007)36[639:CHANS]2.0.CO;2

Lockwood JL, Welbourne DJ, Romagosa CM, Cassey P, Mandrak NE, Strecker A, Leung B, Stringham OC, Udell B, Episcopio-Sturgeon DJ, Tlusty MF, Sinclair J, Springborn MR, Pienaar EF, Rhyne AL, Keller R (2019) When pets become pests: the role of the exotic pet trade in producing invasive vertebrate animals. Frontiers in Ecology and the Environment 17: 323-330. https://doi.org/10.1002/fee.2059

Lodge DM, Lewis MA, Shogren JF, Keller RP (2009) Introduction to biological invasions: biological, economic and social perpectives. In: Keller RP, Lodge DM, Lewis MA, Shogren JF (Eds) Bioeconomics of Invasive Species. Oxford University Press, New York, 24 pp. 
Mack RN (2003) Global plant dispersal, naturalization, and invasion: pathways, modes and circumstances. In: Ruiz GM, Carlton JT (Eds) Invasive Species: Vectors and Management Strategies. Island Press, Washington, 3-30.

Maki K, Galatowitsch S (2004) Movement of invasive aquatic plants into Minnesota (USA) through horticultural trade. Biological Conservation 118: 389-396. https://doi. org/10.1016/j.biocon.2003.09.015

Marbuah G, Gren I-M, McKie B (2014) Economics of harmful invasive species: a review. Diversity 6: 500-523. https://doi.org/10.3390/d6030500

Niemiec RM, Ardoin NM, Wharton CB, Asner GP (2016) Motivating residents to combat invasive species on private lands. Ecology and Society 21: 1-30. https://doi.org/10.5751/ ES-08362-210230

Niemiec RM, Ardoin NM, Wharton CB, Brewer FK (2017) Civic and natural place attachment as correlates of resident invasive species control behavior in Hawaii. Biological Conservation 209: 415-422. https://doi.org/10.1016/j.biocon.2017.02.036

Nuñez MA, Kuebbing S, Dimarco RD, Simberloff D (2012) Invasive species: to eat or not to eat, that is the question. Conservation Letters 5: 334-341. https://doi.org/10.1111/ j.1755-263X.2012.00250.x

Nuñez MA, Simberloff D (2005) Invasive species and the cultural keystone species concept. Ecology and Society 10(1): r4. https://doi.org/10.5751/ES-01342-1001r04

Parker DC, Hessl A, Davis SC (2008) Complexity, land-use modeling, and the human dimension: fundamental challenges for mapping unknown outcome spaces. Geoforum 39: 789-804. https://doi.org/10.1016/j.geoforum.2007.05.005

Patoka J, Magalhães ALB, Kouba A, Faulkes Z, Jerikho R, Vitule JRS (2018) Invasive aquatic pets: failed policies increase risks of harmful invasions. Biodiversity and Conservation 27: 3037-3046. https://doi.org/10.1007/s10531-018-1581-3

Pauly D, Christensen V, Dalsgaard J, Froese R, Torres F (1998) Fishing down marine food webs. Science 279: 860-863. https://doi.org/10.1126/science.279.5352.860

Pergl J, Brundu G, Harrower CA, Cardoso AC, Genovesi P, Katsanevakis S, Lozano V, Perglová I, Rabitsch W, Richards G, Roques A, Rorke SL, Scalera R, Schönrogge K, Stewart A, Tricarico E, Tsiamis K, Vannini A, Vilà M, Zenetos A, Roy HE (2020) Applying the Convention on Biological Diversity Pathway Classification to alien species in Europe. In: Wilson JR, Bacher S, Daehler CC, Groom QJ, Kumschick S, Lockwood JL, Robinson TB, Zengeya TA, Richardson DM (Eds) Frameworks used in Invasion Science. NeoBiota 62: 333-363. https://doi.org/10.3897/neobiota.62.53796

Perrings C, Dehnen-Schmutz K, Touza J, Williamson M (2005) How to manage biological invasions under globalization. Trends in Ecology \& Evolution 20: 212-215. https://doi. org/10.1016/j.tree.2005.02.011

Pinkerton E, John L (2008) Creating local management legitimacy. Marine Policy 32: 680-691. https://doi.org/10.1016/j.marpol.2007.12.005

Polák J, Rádlová S, Janovcová M, Flegr J, Landová E, Frynta D (2019) Scary and nasty beasts: self-reported fear and disgust of common phobic animals. British Journal of Psychology 111: 297-321. https://doi.org/10.1111/bjop.12409

Poland TM, Emery MR, Ciaramitaro T, Pigeon E, Pigeon A (2017) Emerald ash borer, black ash, and Native American basketmaking. In: Freedman E, Meuzil M (Eds) Biodiversity, 
Conservation, and Environmental Management in the Great Lakes Basin. Routledge (London): Chapter 11. https://doi.org/10.4324/9781315268774-11

Potgieter LJ, Cadotte MW (2020) The application of selected invasion frameworks to urban ecosystems. In: Wilson JR, Bacher S, Daehler CC, Groom QJ, Kumschick S, Lockwood JL, Robinson TB, Zengeya TA, Richardson DM (Eds) Frameworks used in Invasion Science. NeoBiota 62: 365-386. https://doi.org/10.3897/neobiota.62.50661

Preiser R, Biggs R, De Vos A, Folke C (2018) Social-ecological systems as complex adaptive systems: organizing principles for advancing research methods and approaches. Ecology and Society 23: 1-46. https://doi.org/10.5751/ES-10558-230446

Pyšek P, Bacher S, Kühn I, Novoa A, Catford JA, Hulme PE, Pergl J, Richardson DM, Wilson JRU, Blackburn TM (2020) MAcroecological Framework for Invasive Aliens (MAFIA): disentangling large-scale context dependence in biological invasions. In: Wilson JR, Bacher S, Daehler CC, Groom QJ, Kumschick S, Lockwood JL, Robinson TB, Zengeya TA, Richardson DM (Eds) Frameworks used in Invasion Science. NeoBiota 62: 407-462. https://doi.org/10.3897/neobiota.62.52787

Rabemananjara FCE, Rasoamampionona Raminosoa N, Ravoahangimalala Ramilijaona O, Andreone F, Bora P, Carpenter AI, Glaw F, Razafindrabe T, Vallan D, Vieites DR (2008) Malagasy poison frogs in the pet trade: a survey of levels of exploitation of species in the genus Mantella. Amphibian and Reptile Conservation 5: 3-16.

Ricciardi A (2007) Are modern biological invasions an unprecedented form of global change? Conservation Biology. 21: 329-336. https://doi.org/10.1111/j.15231739.2006.00615.x

Richardson DM, Pyšek P, Rejmánek M, Barbour MG, Panetta FD, West CJ (2000) Naturalization and invasion of alien plants: concepts and definitions. Diversity and Distributions 6: 93-107. https://doi.org/10.1046/j.1472-4642.2000.00083.x

Robinson CJ, Smyth D, Whitehead PJ (2005) Bush tucker, bush pets, and bush threats: cooperative management of feral animals in Australia's Kakadu National Park. Conservation Biology 19: 1385-1391. https://doi.org/10.1111/j.1523-1739.2005.00196.x

Scheffers BR, Oliveira BF, Lamb I, Edwards DP (2019) Global wildlife trade across the tree of life. Science 366: 71-76. https://doi.org/10.1126/science.aav5327

Schroth G, Ruf F (2014) Farmer strategies for tree crop diversification in the humid tropics. A review. Agronomy for Sustainable Development 34: 139-154. https://doi.org/10.1007/ s13593-013-0175-4

Schüttler E, Rozzi R, Jax K (2011) Towards a societal discourse on invasive species management: a case study of public perceptions of mink and beavers in Cape Horn. Journal for Nature Conservation 19: 175-184. https://doi.org/10.1016/j.jnc.2010.12.001

Seebens H, Blackburn TM, Dyer EE, Genovesi P, Hulme PE, Jeschke JM, Pagad S, Pyšek P, Winter M, Arianoutsou M, Bacher S, Blasius B, Brundu G, Capinha C, Celesti-Grapow L, Dawson W, Dullinger S, Fuentes N, Jäger H, Kartesz J, Kenis M, Kreft H, Kühn I, Lenzner B, Liebhold A, Mosena A, Moser D, Nishino M, Pearman D, Pergl J, Rabitsch W, RojasSandoval J, Roques A, Rorke S, Rossinelli S, Roy HE, Scalera R, Schindler S, Štajerová K, Tokarska-Guzik B, van Kleunen M, Walker K, Weigelt P, Yamanaka T, Essl F (2017) No saturation in the accumulation of alien species worldwide. Nature Communications 8: 14435. https://doi.org/10.1038/ncomms14435 
Semenya SS, Tshisikhawe MP, Potgieter MT (2012) Invasive alien plant species: a case study of their use in the Thulamela Local Municipality, Limpopo Province, South Africa. Scientific Research and Essays 7: 2363-2369. https://doi.org/10.5897/SRE11.2075

Shackleton RT, Biggs R, Richardson DM, Larson BMH (2018) Social-ecological drivers and impacts of invasion-related regime shifts: consequences for ecosystem services and human wellbeing. Environmental Science \& Policy 89: 300-314. https://doi.org/10.1016/j.envsci.2018.08.005

Shackleton RT, Larson BMH, Novoa A, Richardson DM, Kull CA (2019) The human and social dimensions of invasion science and management. Journal of Environmental Management 229: 1-9. https://doi.org/10.1016/j.jenvman.2018.08.041

Shackleton RT, Le Maitre DC, van Wilgen BW, Richardson DM (2015) Use of non-timber forest products from invasive alien Prosopis species (mesquite) and native trees in South Africa: implications for management. Forest Ecosystems 2: 1-16. https://doi.org/10.1186/ s40663-015-0040-9

Simberloff D (2009) We can eliminate invasions or live with them. Successful management projects BT - Ecological impacts of non-native invertebrates and fungi on terrestrial ecosystems. In: Langor DW, Sweeney J (Eds) Ecological Impacts of Non-Native Invertebrates and Fungi on Terrestrial Ecosystems. Springer, The Netherlands, Dordrecht, 149-157. https://doi.org/10.1007/978-1-4020-9680-8_11

Simberloff D, Stiling P (1996) How risky is biological control? Ecology 77: 1965-1974. https://doi.org/10.2307/2265693

Simberloff D, Von Holle B (1999) Positive interactions of nonindigenous species: invasional meltdown? Biological Invasions 1: 21-32. https://doi.org/10.1023/A:1010086329619

Sinclair JS, Lockwood JL, Hasnain S, Cassey P, Arnott SE (2020) A framework for predicting which non-native individuals and species will enter, survive, and exit human-mediated transport. Biological Invasions 22: 217-231. https://doi.org/10.1007/s10530-019-02086-7

Suarez AV, Holway DA, Case TJ (2001) Patterns of spread in biological invasions dominated by long-distance jump dispersal: insights from Argentine ants. Proceedings of the National Academy of Sciences 98: 1095-1100. https://doi.org/10.1073/pnas.98.3.1095

Trigger DS (2008) Indigeneity, ferality, and what 'belongs' in the Australian bush: aboriginal responses to 'introduced' animals and plants in a settler-descendant society. Journal of the Royal Anthropological Institute 14: 628-646. https://doi.org/10.1111/j.1467-9655.2008.00521.x

Verling E, Ruiz GM, Smith LD, Galil B, Miller AW, Murphy KR (2005) Supply-side invasion ecology: characterizing propagule pressure in coastal ecosystems. Proceedings of the Royal Society B: Biological Sciences 272: 1249-1256. https://doi.org/10.1098/rspb.2005.3090

Vilà M, Hulme PE (2017) Non-native species, ecosystem services, and human well-being. In: Vilà M, Hulme PE (Eds) Impact of Biological Invasions on Ecosystem Services. Springer International Publishing, Cham, 14 pp. https://doi.org/10.1007/978-3-319-45121-3_1

Vimercati G, Davies SJ, Hui C, Measey J (2017) Does restricted access limit management of invasive urban frogs? Biological Invasions 19: 3659-3674. https://doi.org/10.1007/ s10530-017-1599-6

Wilson JRU, Dormontt EE, Prentis PJ, Lowe AJ, Richardson DM (2009) Something in the way you move: dispersal pathways affect invasion success. Trends in Ecology and Evolution 24: 136-144. https://doi.org/10.1016/j.tree.2008.10.007 